Provided for non-commercial research and education use. Not for reproduction, distribution or commercial use.

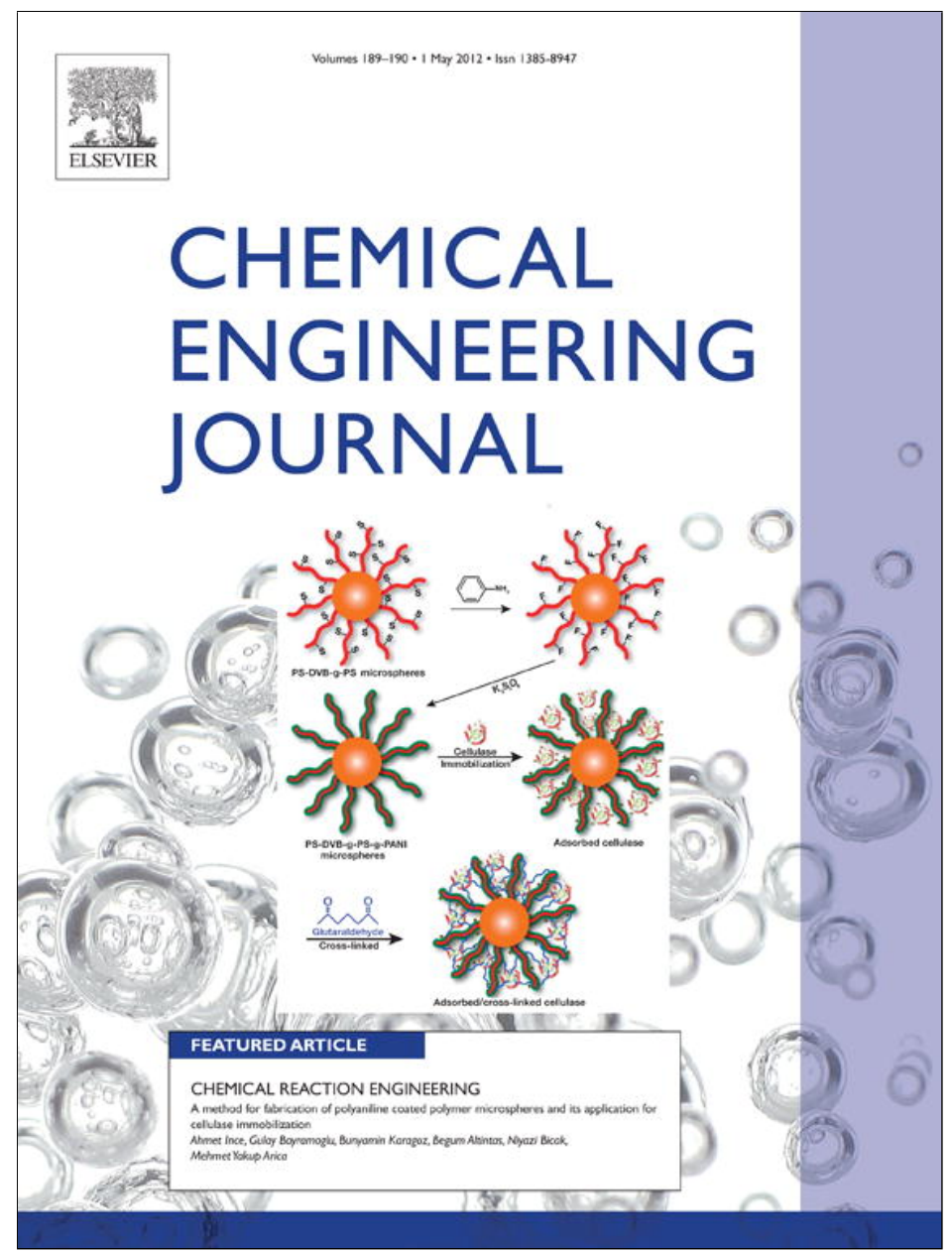

This article appeared in a journal published by Elsevier. The attached copy is furnished to the author for internal non-commercial research and education use, including for instruction at the authors institution and sharing with colleagues.

Other uses, including reproduction and distribution, or selling or licensing copies, or posting to personal, institutional or third party websites are prohibited.

In most cases authors are permitted to post their version of the article (e.g. in Word or Tex form) to their personal website or institutional repository. Authors requiring further information regarding Elsevier's archiving and manuscript policies are encouraged to visit:

http://www.elsevier.com/copyright 


\title{
Removal of basic dyes in binary system by adsorption using rarasaponin-bentonite: Revisited of extended Langmuir model
}

\author{
Alfin Kurniawan, Hogiartha Sutiono, Nani Indraswati, Suryadi Ismadji* \\ Department of Chemical Engineering, Widya Mandala Surabaya Catholic University, Kalijudan 37, Surabaya 60114, Indonesia
}

\section{A R T I C L E I N F O}

\section{Article history:}

Received 23 January 2012

Received in revised form 23 February 2012

Accepted 23 February 2012

\section{Keywords:}

Adsorption

Malachite green

Methylene blue

Binary system

Extended Langmuir

\begin{abstract}
A B S T R A C T
The preparation of organo-bentonite via microwave radiation using natural surfactant (i.e. rarasaponin) from the tropical soapfruit pericarps of Sapindus rarak was conducted in this work. The adsorption performance of bentonite and its modified form was studied for the removal of two dyes (i.e. methylene blue and malachite green) in single and binary systems. Langmuir and Freundlich models were applied to evaluate adsorption equilibrium data in single systems. From physical meaning interpretation of the model parameters, it was found that Langmuir model gave the best representation. A new approach in representing binary experimental isotherms with extended Langmuir model incorporating fractional surface coverage in 3D mesh plot was also verified. The results show that recently proposed modification of extended Langmuir model could be used to evaluate binary adsorption data well with reasonable fitted parameter value.
\end{abstract}

(C) 2012 Elsevier B.V. All rights reserved.

\section{Introduction}

The increasing environmental pollution from domestic and industrial effluents, particularly in the developing countries is of major concern. One kind of contaminants that are frequently polluting the water systems are dyes. Dyes are complex aromatic substances that indispensable in many industries such as textile, paper, paint, leather, pigment, and pharmaceutical to impart color. Compared with natural dyes, synthetic dyes are superior in terms of color availability, permanent, ease to use, quick-setting and ensured by accurate formulas [1]. More than 100,000 kinds of synthetic dyes are commercially available with total amount of production reach $7 \times 10^{5}$ tonnes annually [2]. Of these, malachite green (MG) and methylene blue (MB) are two kinds of dyes that are most widely used among all other dyes in basic dye class [3,4]. Malachite green (4-[(4-dimethylaminophenyl)phenylmethyl]- $N, N$-dimethylaniline) is a triphenylcarbenium salts, which composed of triarylmethane ring as the chromophore structure. Its applications are widely found in the paper, leather, silk and wool industries to color such products and aquaculture field as a biocide, fungicide and parasiticide therapeutic agent [3]. In other hand, methylene blue (3,7-bis(dimethylamino)phenothiazin-5ium chloride) is a thiazine dye that used as redox indicator in the chemistry field, bacteria stain and indicator of viable yeast cell in the biology field and dyestuff for cotton, wool, paper and silk $[4,5]$.

\footnotetext{
* Corresponding author. Tel.: +62 313891264; fax: +62 313891267

E-mail address: suryadiismadji@yahoo.com (S. Ismadji).
}

Despite of the commercial importance of MG and MB dyes, the presence of these substances in natural environment (e.g. water bodies) even in trace quantities are highly undesirable for both toxicological and esthetical reasons. Moreover, the prolonged accumulation of these dyes in human body via food chain can cause several diseases and disorders due to their carcinogenic and mutagenic activity [6,7]. Therefore, the removal of these dyes from waste effluents is of interest prior to release into natural environment.

Several conventional methods are available for the treatment and decontamination of dyes including physical, chemical and biological methods such as ozonation, photocatalysis, chemical oxidation, membrane filtration, flotation, coagulation, aerobic and anaerobic microbial degradation, enzyme degradation and adsorption $[8,9]$. However, most of them are considered ineffective for handling colored effluents due to chemical stability and low biodegradability of most dyes. In other hand, adsorption has proven to be a promising and cost effective method for this purpose. Cost is actually an important parameter for the selection of the adsorbent materials in designing adsorption system. In recent years, attention has been focused on the search and development of various low cost alternative adsorbents for dyes removal, including agricultural solid wastes, industrial by-products and natural materials [10-12].

Clay has been emerged as potential natural adsorbents in the adsorption field due to their abundant reserve, low cost, high chemical and mechanical stabilities as well as high adsorptive properties. The applications of clay-based adsorbents for the removal of dyes have received growing attentions in the last decade [10,13-15]. Bentonite is a type of natural clay mineral that abundantly found in 
Table 1

Information on the methylene blue and malachite green dyes.

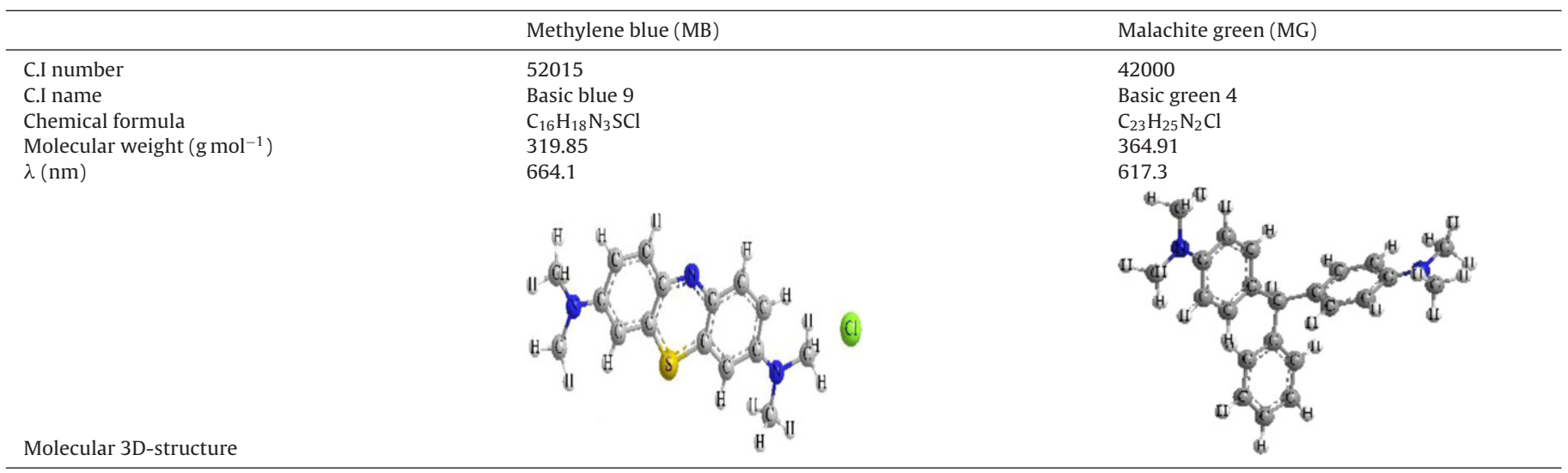

many countries, including Indonesia. It is originated from the alteration of glass-rich volcanic rocks such as tuffs and ash deposits that composed of montmorillonite mineral as the main constituent [16]. The surface properties of bentonite can be remarkably enhanced by replacing inorganic metal cations (typically $\mathrm{Na}^{+}$and $\mathrm{Ca}^{2+}$ ) at bentonite interlayer with organic cations. This substitution results in the hydrophobic surface nature of bentonite, which is suitable for the adsorption of organic substances. Several studies have reported on the modification of bentonite using various surfactants such as CTAB, CDBAC, CPC, and TMAB for dye removal [17-19]. However, the use of synthetic surfactants often causes environmental issues and need an extra cost for the treatment of unused chemicals. For this reason, the utilization of natural surfactant (i.e. rarasaponin) from the tropical soapfruit pericarps of Sapindus rarak is highlighted in this work.

This work deals with the removal of two basic dyes (i.e. MB and $\mathrm{MG}$ ) in single and binary systems using Trenggalek bentonite modified with rarasaponin surfactant. To date, there is no report on the removal of these dyes in binary system using rarasaponin-bentonite. A new approach of extended Langmuir model for representation of experimental isotherm in binary system was also proposed. Most of studies on the binary adsorption of various substances used such model to evaluate adsorption equilibrium data by introducing original $K_{\mathrm{L}}$ and $q_{\mathrm{m}}$ parameters from single system [20-24]. However, such procedure cannot be precisely implemented in binary system, where the competition between adsorbate components for the adsorption sites occurs and may act as the sorption-controlling factor. Therefore, we proposed a revisited mathematic expression of $q_{\mathrm{m}}$ and $K_{\mathrm{L}}$ parameters in extended Langmuir model for binary system by inclusion of fractional surface coverage.

\section{Materials and methods}

\subsection{Materials}

Malachite green (A.R. Grade, purity $>96 \%$ ) and methylene blue (A.R. Grade, purity > 95\%) were purchased from Sigma Aldrich and used as received. Some information about these dyes and their molecular structures are summarized in Table 1. Rarasaponin surfactant used in this study was isolated from the tropical fruit pericarps of $S$. rarak by extraction process. The detail procedure of rarasaponin extraction can be found elsewhere [10].

\subsection{Preparation of adsorbents}

Bentonite used in this study was collected from the mining site located in Trenggalek, East Java, Indonesia. The type of bentonite from this location is Ca-bentonite. Prior to use, bentonite was purified using $\mathrm{H}_{2} \mathrm{O}_{2}$ solution according to the procedure reported by Rahardjo et al. [25]. The cation exchange capacity (CEC) of bentonite was determined based on the ASTM C837-99 standard procedure and found to be $0.537 \mathrm{meq} / \mathrm{g}$ clay. The mineral compositions of bentonite were analyzed by atomic absorption spectrophotometry, in a FAAS Shimadzu AA6200 and the results are given as follows: $\mathrm{SiO}_{2}$ 57.8\%, $\mathrm{Al}_{2} \mathrm{O}_{3}$ 21.6\%, $\mathrm{Fe}_{2} \mathrm{O}_{3}$ 6.4\%, $\mathrm{CaO} 4.3 \%, \mathrm{Na}_{2} \mathrm{O} 1.9 \%, \mathrm{MgO} 1.5 \%, \mathrm{~K}_{2} \mathrm{O}$ $0.7 \%$ and $\mathrm{H}_{2} \mathrm{O} 5.8 \%$.

Rarasaponin-bentonite was synthesized by following procedure: $10 \mathrm{~g}$ of bentonite was dispersed into $50 \mathrm{~mL}$ distilled water containing rarasaponin surfactant with concentration equivalent to 1.5 times of the CEC of bentonite. The mixture was then subjected to heating in a microwave oven (National NN-S327 WF) for $60 \mathrm{~s}$ at heating power of $700 \mathrm{~W}$. The resulting rarasaponin-bentonite was then repeatedly washed with distilled water and dried in an oven at $100^{\circ} \mathrm{C}$ for $24 \mathrm{~h}$.

\subsection{Characterizations of adsorbents}

The pore structure of the adsorbents was analyzed by nitrogen adsorption at $77 \mathrm{~K}$, in a Quadrasorb SI at relative pressure $\left(p / p^{0}\right)$ range from approximately 0.001 to 0.995 . The samples were degassed in vacuum condition at $423 \mathrm{~K}$ for at least $24 \mathrm{~h}$ prior to the adsorption analysis. The surface area of the adsorbents $\left(S_{\mathrm{BET}}\right)$ was determined by standard BET equation applied at relative pressure range from 0.06 to 0.3 . The total pore volume $\left(V_{\mathrm{T}}\right)$ of the adsorbents was calculated from the gas adsorption data at the highest relative pressure $\left(p / p^{0}=0.995\right)$. The pore size distributions (PSDs) of the adsorbents were evaluated by Density Functional Theory (DFT) model available within the instrument with medium regularization.

The layer structure of bentonite and rarasaponin-bentonite was characterized by XRD method (Rigaku Miniflex Goniometer). The powder XRD patterns of the samples were collected at $30 \mathrm{kV}$ and $15 \mathrm{~mA}$, with a Ni-filtered CuK $\alpha$ radiation $(\lambda=1.542 \AA)$ at a step size of $0.01^{\circ}$.

The surface functional groups of the adsorbents were analyzed by infrared spectroscopy, in a FTIR Shimadzu 8400 s spectrometer using $\mathrm{KBr}$ disk pelleting technique. The spectra data of the samples were recorded in the mid-IR wavenumber range $\left(4000-500 \mathrm{~cm}^{-1}\right)$.

The $\mathrm{pH}_{\mathrm{pzc}}$ (point of zero charge) of bentonite and rarasaponin-bentonite were determined by $\mathrm{pH}$-drift procedure [26], and found to be 2.86 and 3.02 , respectively.

\subsection{Adsorption experiments}

For single systems, the stock solutions of dyes at initial concentration of $1000 \mathrm{mg} / \mathrm{L}(2.74 \mathrm{mmol} / \mathrm{L}-\mathrm{MG}$ and $2.67 \mathrm{mmol} / \mathrm{L}-\mathrm{MB})$ 
were prepared by dissolving a known amount of dye into distilled water. Adsorption isotherm experiments were carried out by adding various mass of adsorbent into a series of conical flasks containing $100 \mathrm{~mL}$ of dye solution. The flasks were then shaken in a Memmert shaking water bath at various temperatures $(303.15 \mathrm{~K}$, $323.15 \mathrm{~K}$ and $343.15 \mathrm{~K}$ ) within $1-2 \mathrm{~h}$ until equilibrium condition reached. Subsequently, the mixture was centrifuged at $4500 \mathrm{rpm}$ for $5 \mathrm{~min}$ to remove solid particles. The resultant supernatant was taken and analyzed its residual concentration using a Shimadzu UV/Vis-1700 spectrophotometer at maximum absorbance wavelengths $(\lambda)$ of $617.3 \mathrm{~nm}$ for MG and $664.1 \mathrm{~nm}$ for MB, respectively. The effect of $\mathrm{pH}$ was also studied at $\mathrm{pH}$ range of 3-10. To adjust the $\mathrm{pH}$, an appropriate amount of $0.1 \mathrm{~N} \mathrm{HCl}$ or $\mathrm{NaOH}$ solutions was added to the system. The calibration curves for dyes in single systems were prepared by measuring the absorbance of different concentrations of the dyes. The amount of dye adsorbed at equilibrium per unit of mass, $q_{\mathrm{e}}$, was calculated as follows:

$q_{e}=\frac{\left(C_{0}-C_{e}\right) \times V}{m}$

where $C_{0}$ and $C_{\mathrm{e}}$ are the initial and equilibrium concentrations of dye in solution $(\mathrm{mmol} / \mathrm{L})$, respectively, $V$ is the volume of dye solution (L) and $m$ is the mass of the adsorbents used $(\mathrm{g})$.

For binary systems, the dye mixtures were prepared by adding a known amount of MB dye $(0.25 \mathrm{~g}, 0.5 \mathrm{~g}, 0.75 \mathrm{~g}$ and $1 \mathrm{~g})$ into $1 \mathrm{~L}$ of MG solutions with initial concentration of $2.74 \mathrm{mmol} / \mathrm{L}$. Adsorption isotherm experiments were conducted based on the procedure in single system. The residual dye concentration in binary system was determined by measuring MG and MB dyes at $\lambda_{1}$ and $\lambda_{2}$, respectively, to give optical densities of $d_{1}$ and $d_{2}$, as previously described by Choy et al. [20]:

$$
\begin{aligned}
C_{\mathrm{e}, \mathrm{MG}} & =\frac{k_{\mathrm{MB}, 2} d_{1}-k_{\mathrm{MB}, 1} d_{2}}{k_{\mathrm{MG}, 1} k_{\mathrm{MB}, 2}-k_{\mathrm{MG}, 2} k_{\mathrm{MB}, 1}} \\
C_{\mathrm{e}, \mathrm{MB}} & =\frac{k_{\mathrm{MG}, 1} d_{2}-k_{\mathrm{MG}, 2} d_{1}}{k_{\mathrm{MG}, 1} k_{\mathrm{MB}, 2}-k_{\mathrm{MG}, 2} k_{\mathrm{MB}, 1}}
\end{aligned}
$$

where $k_{\mathrm{MG}, 1}, k_{\mathrm{MG}, 2}, k_{\mathrm{MB}, 1}$ and $k_{\mathrm{MB}, 2}$ are the calibration constants for MG and MB dyes at the two wavelengths, $\lambda_{1}$ and $\lambda_{2}$, respectively. The amount of " $i$ " dye adsorbed at equilibrium per unit of mass, $q_{\mathrm{e}, i}$, was calculated as follows:

$q_{\mathrm{e}, i}=\frac{\left(C_{0, i}-C_{\mathrm{e}, i}\right) \times V}{m}$

where $C_{0, i}$ and $C_{\mathrm{e}, i}$ are the initial and equilibrium concentrations of " $i$ " dye in the mixture $(\mathrm{mmol} / \mathrm{L})$, respectively, $V$ is the volume of dye mixture (L) and $m$ is the mass of the adsorbents used ( $\mathrm{g}$ ).

\section{Results and discussion}

\subsection{Pore characteristics of adsorbents}

The pore structure of the solid is a critical variable in the adsorption process since it determines the failure or success of such process from both equilibria and kinetic viewpoints. In this work, the pore structure of bentonite and rarasaponin-bentonite was analyzed by nitrogen adsorption at $77 \mathrm{~K}$ (Supporting information Fig. S1). From this figure, it can be confirmed the largely mesoporosity on the surface of bentonite and rarasaponin-bentonite, as denoted from the adsorption-desorption isotherm curves that exhibit type-IV shape based on IUPAC classification. Moreover, the mesoporous characters of the adsorbents were also observed from the hysteresis curve that lies between adsorption and desorption isotherm curves at relative pressure $\left(p / p^{0}\right)$ above 0.5 (Supporting information Fig. S1).

The surface area $\left(S_{\mathrm{BET}}\right)$ of rarasaponin-bentonite was lower than bentonite $\left(45.3 \mathrm{~m}^{2} / \mathrm{g}\right.$ vs. $\left.51.8 \mathrm{~m}^{2} / \mathrm{g}\right)$ while its total pore volume $\left(V_{\mathrm{T}}\right)$ is higher than bentonite $\left(0.49 \mathrm{~cm}^{3} / \mathrm{g}\right.$ vs. $\left.0.41 \mathrm{~cm}^{3} / \mathrm{g}\right)$. This is likely due to the formation of larger pore as a result of intercalation of organic modifier (i.e. acetyl cation) at the interlayer spacing of bentonite. Such pore characteristics are also evidenced from DFT result (Supporting information Fig. S2).

\subsection{Layer characteristics of adsorbents}

XRD analysis can be used as useful tool to characterize the layer structure of bentonite before and after modification. The powder XRD patterns of bentonite and rarasaponin-bentonite are shown in Fig. 1. From Fig. 1, it can be seen the reflection peak for Ca-bentonite at $2 \theta=5.92^{\circ}$ with a $d(001)$-spacing value of $14.93 \AA$. The presence of other mineral compounds such as kaolin $(\mathrm{K})$, quartz $(\mathrm{Q})$ and calcite (Ca) in bentonite were also observed in the reflections relative to the planes $\mathrm{K}\left(\begin{array}{lll}0 & 0 & 1\end{array}\right), \mathrm{Q}\left(\begin{array}{lll}1 & 0 & 1\end{array}\right)$ and $\mathrm{Ca}\left(\begin{array}{ll}1 & 0\end{array}\right)$, respectively.

After modification with rarasaponin surfactant, the reflection peak of rarasaponin-bentonite was shifted to lower angle of $2 \theta=5.77^{\circ}$ with an increase in $d(001)$-spacing value to $15.87 \AA$. The slightly increase in the $d(001)$-spacing of rarasaponin-bentonite denotes that not all the interlayer sheets have been intercalated by acetyl cations. Such phenomena result in the expansion of the 2:1 interlamellar distance and later will promote the adsorption capacity of rarasaponin-bentonite for dyes removal.

\subsection{Surface chemistry characteristics of adsorbents}

Infrared spectroscopy analysis (FT-IR) was performed to probe the conformation of surfactant cation species at the interlayer of rarasaponin-bentonite and identify the vibrational frequency changes of surface groups of the adsorbents, which are involved in the sorption process (figure not shown here). The FT-IR assignments of bentonite and rarasaponin-bentonite are summarized in Table 2 . From Table 2, it can be seen the formation of rarasaponin-bentonite proceeded via ion exchange mechanism between inorganic interlayer cation (i.e. $\left.\mathrm{Ca}^{2+}\right)$ and acetyl cation $\left(\mathrm{C}_{2} \mathrm{H}_{3} \mathrm{O}^{+}\right)$, as indicated from the presence of $\mathrm{C}=0$ stretch vibration at $1712 \mathrm{~cm}^{-1}$. Other FT-IR assignments in bentonite, which are the characteristics of montmorillonite clay also noticed such as $\mathrm{Al}-\mathrm{O}-\mathrm{Si}$ deformation at $524 \mathrm{~cm}^{-1}$; $\mathrm{Si}-\mathrm{O}$ stretch of quartz at $677 \mathrm{~cm}^{-1}$; Al-Al-OH deformation at $923 \mathrm{~cm}^{-1}$; $\mathrm{Si}-\mathrm{O}$ stretch (in-plane) of tetrahedral sheet at $1040 \mathrm{~cm}^{-1}$; $\mathrm{O}-\mathrm{H}$ bend for adsorbed $\mathrm{H}_{2} \mathrm{O}$ at the interlayer of clay at $1638 \mathrm{~cm}^{-1}$ and $\mathrm{O}-\mathrm{H}$ stretch of aluminol $(\mathrm{Al}-\mathrm{OH})$ or silanol $(\mathrm{Si}-\mathrm{OH})$ at $3621 \mathrm{~cm}^{-1}$.

The FTIR assignments of bentonite loaded with dyes (i.e. MB and MG) were also given in Table 2. From this table, it can be seen the presence of assignments of $\mathrm{N}-\mathrm{O}$ asymmetric stretch and S-O stretch at $1528 \mathrm{~cm}^{-1}$ and $973 \mathrm{~cm}^{-1}$, respectively. These assignments may reveal to the binding of dye molecules onto the bentonite surface, which occur via electrostatic dipole-dipole interaction between negatively charged oxygen atoms of the deprotonated silanol sites and positively charged site of the dye molecules (i.e. $\mathrm{N}^{+}$for $\mathrm{MG}$ and $\mathrm{S}^{+}$for $\mathrm{MB}$ ). Moreover, the presence of other assignment at $1592 \mathrm{~cm}^{-1}$, attributed to the aromatic $\mathrm{C}=\mathrm{C}$ stretch of the dye structure was also observed. The binding of the dye moieties in the silanol sites was also confirmed from the shifting of OH-stretch in the silanol species from $3621 \mathrm{~cm}^{-1}$ to $3563 \mathrm{~cm}^{-1}$ and reduction in its corresponding peak energy. Similar observations were also noticed in the FTIR assignments for rarasaponin-bentonite loaded with dyes.

\subsection{Effect of $\mathrm{pH}$}

The $\mathrm{pH}$ is regarded as a crucial parameter in the adsorption process since it may control the uptake mechanism of the adsorbate as well as influence the adsorption sites (e.g. the potential charge 
Table 2

FTIR assignments of pristine and dye-loaded adsorbents.

\begin{tabular}{|c|c|c|c|c|}
\hline \multirow[t]{2}{*}{ FTIR assignments } & \multicolumn{4}{|c|}{ Wavenumber $\left(\mathrm{cm}^{-1}\right)$} \\
\hline & Bentonite & $\begin{array}{l}\text { rarasaponin- } \\
\text { bentonite }\end{array}$ & Bentonite + dyes & $\begin{array}{l}\text { Rarasaponin- } \\
\text { bentonite + dyes }\end{array}$ \\
\hline $\mathrm{O}-\mathrm{H}$ stretch $(\mathrm{Si}-\mathrm{OH}$ or $\mathrm{Al}-\mathrm{OH})$ & 3621 & 3614 & 3563 & 3548 \\
\hline $\mathrm{C}=\mathrm{O}$ stretch $\left(\mathrm{C}_{2} \mathrm{H}_{3} \mathrm{O}^{+}\right)$ & - & 1712 & - & 1706 \\
\hline $\mathrm{O}-\mathrm{H}$ bend (adsorbed $\mathrm{H}_{2} \mathrm{O}$ at the interlayer of clay) & 1638 & 1636 & 1638 & 1638 \\
\hline $\mathrm{C}=\mathrm{C}$ stretch (aromatic ring) & - & - & 1592 & 1581 \\
\hline $\mathrm{N}-\mathrm{O}$ stretch (asymmetric stretch) & - & - & 1528 & 1542 \\
\hline $\mathrm{Si}-\mathrm{O}$ stretch (in-plane) for tetrahedral sheet & 1040 & 1017 & 1025 & 1032 \\
\hline $\mathrm{S}-\mathrm{O}$ stretch & - & - & 973 & 968 \\
\hline $\mathrm{Al}-\mathrm{Al}-\mathrm{OH}$ & 923 & 916 & 916 & 916 \\
\hline $\mathrm{Si}-\mathrm{O}$ stretch (quartz) & 677 & 675 & 690 & 682 \\
\hline $\mathrm{Al}-\mathrm{O}-\mathrm{Si}$ & 524 & 522 & 523 & 524 \\
\hline
\end{tabular}

of the site) on the solid surface. In the case of dye adsorption, the changes in the structural and colour stabilities as well as degree of ionization for such adsorbate is also dependent on the $\mathrm{pH}$ of the solution [27]. The effect of $\mathrm{pH}$ on the adsorption of MB and MG dyes onto rarasaponin-bentonite in single system was studied at $\mathrm{pH}$ range of 3-10 and the results are given in Fig. 2 .
As noted in Fig. 2, a gradual increase in the percentage removal for both dyes was observed in the $\mathrm{pH}$ range of 4-7 and reached its maximum at around $\mathrm{pH} 8$. Increasing $\mathrm{pH}$ more than this value would lead to insignificant change in the percentage removal for both dyes. Moreover, a substantial reduction in the color intensity for MG was observed at $\mathrm{pH}>9$ while the color intensity of $\mathrm{MB}$
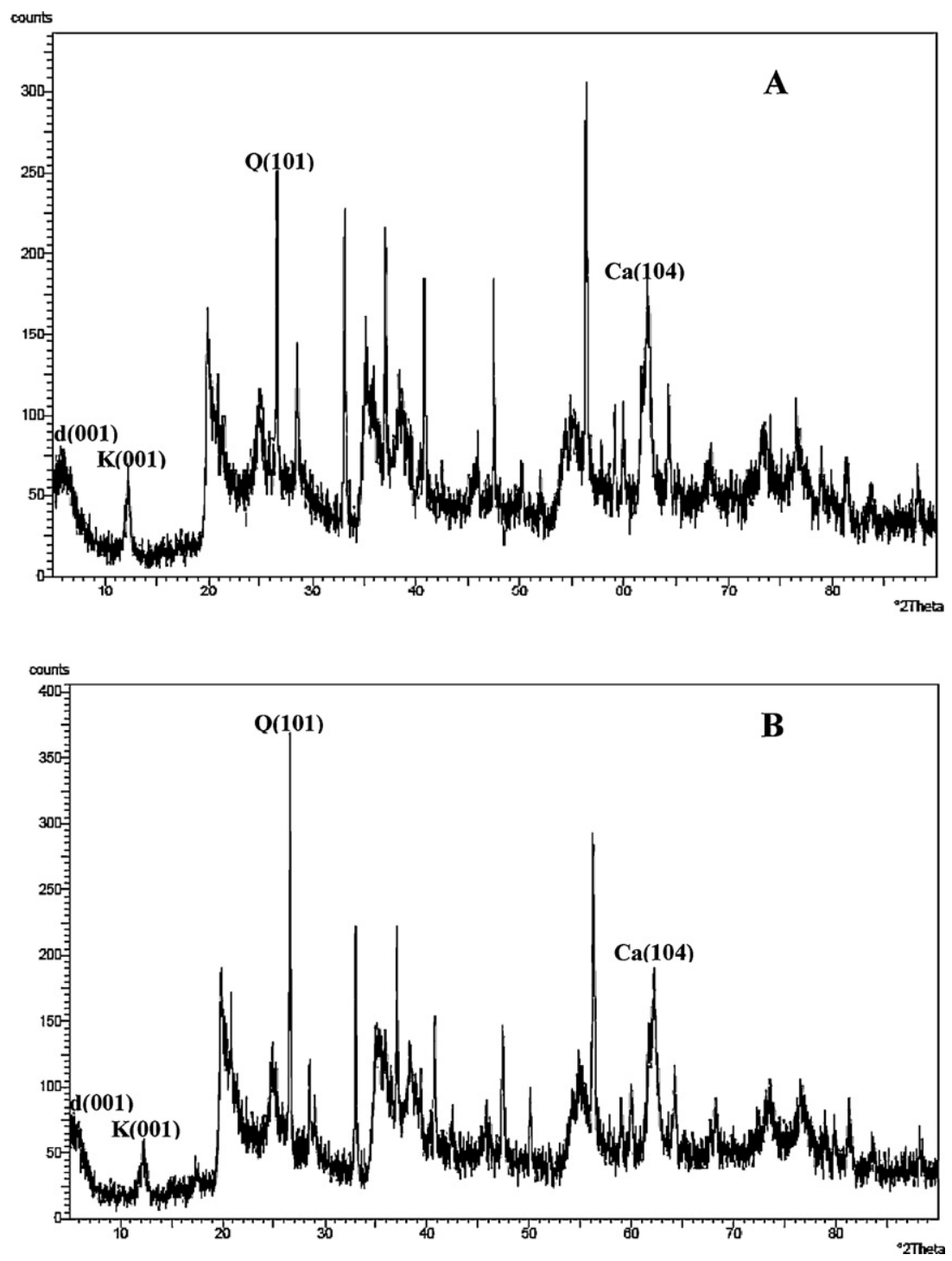

Fig. 1. Powder XRD patterns of bentonite (A) and rarasaponin-bentonite (B). 


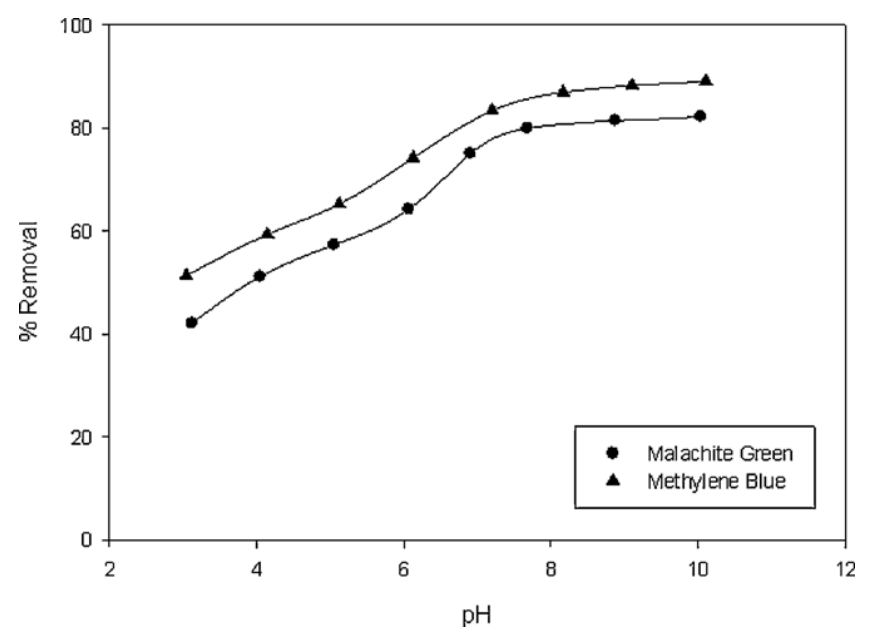

Fig. 2. Effect of $\mathrm{pH}$ on the adsorption of dyes onto rarasaponin-bentonite $\left(C_{0}=2.74 \mathrm{mmol} / \mathrm{L} ; t=2 \mathrm{~h} ; T=303.15 \mathrm{~K}\right)$.

slightly changes from $\mathrm{pH} 8$ to $\mathrm{pH} 10$. Therefore $\mathrm{pH} 8$ was selected as optimum point and used for further experiments in this study. Since both MG and MB are cationic dyes, which have similar $\mathrm{pH}$ value for their highest removal, therefore $\mathrm{pH} 8$ was also used during adsorption experiments in binary system.

In basic solution, the adsorption of cationic dyes was favored due to the presence of negatively charged sites (i.e. deprotonated silanol) on the adsorbent surface, resulting in the electrostatic forces between these groups and positively charged dye molecules. As mentioned in previous paragraph, the $\mathrm{pH}$ of the solution also gives impact on the surface sites of the adsorbent, associated to the protonation and deprotonation of silanol groups $(\equiv \mathrm{Si}-\mathrm{OH})$ as the active sites. The protonation and deprotonation of silanol species take place as follows:

$=\mathrm{Si}-\mathrm{OH}+\mathrm{H}^{+} \rightarrow \equiv \mathrm{Si}-\mathrm{OH}_{2}{ }^{+}, \quad$ whenpH $\mathrm{H}_{\text {solution }}<\mathrm{pH}_{\mathrm{pzc}}$

$\equiv \mathrm{Si}-\mathrm{OH}+\mathrm{OH}^{-} \rightarrow \equiv \mathrm{Si}-\mathrm{O}^{-}+\mathrm{H}_{2} \mathrm{O}, \quad$ whenpH $\mathrm{H}_{\text {solution }}>\mathrm{pH}_{\mathrm{pzc}}$

In acidic solution (e.g. $\mathrm{pH}=3$ ), the adsorption of dyes was retarded due to sorption competition between hydrogen ions $\left(\mathrm{H}^{+}\right)$ and dye molecules for occupancy of the active sites. Moreover, high concentration of $\mathrm{H}^{+}$ions causes the protonation of silanol groups, which resulted in ionic repulsion between cationic dye molecules and protonated silanol sites. As the $\mathrm{pH}$ of the system increases, the concentration of $\mathrm{H}^{+}$ions in bulk solution decreases and the silanol sites become deprotonated, therefore increasing the negative charge density on the adsorbent surface and facilitating the adsorption of dye molecules.

\subsection{Adsorption isotherms}

Adsorption isotherm is the most valuable information in the adsorption studies for the practical and operational design of the sorption system since it describes the distribution of the adsorbate molecules within the solid and liquid phase at equilibrium. By evaluating this aspect, the information on the adsorption kinetics of single component system, adsorption equilibria of multicomponent systems and adsorption kinetics of multicomponent systems can be obtained [28]. In the beginning, the adsorption models such as Langmuir, Freundlich, Sips, Toth, Dubinin-Raduskevich, Redlich-Peterson, Temkin, and Hill are extensively used to describe adsorption in gas phase, but in later, most of them can in principle be extended to liquid phase adsorption. Several studies have reported on the applications of different adsorption models to evaluate various liquid phase adsorption systems [29-33].

\subsubsection{Adsorption isotherms for single system}

In this study, the two-well known adsorption models namely Langmuir and Freundlich were used to evaluate adsorption equilibrium data in single system. Langmuir model(1918) was proposed based on the kinetic principle, that is the adsorption rate is equal to the desorption rate from the surface to maintain zero rate of accumulation when equilibrium is approached [28]. This model also assumed that the adsorption on surface occurs at a finite or definite localized site with no lateral interaction and steric hindrance between the adsorbed species, even on the adjacent sites [34]. The Langmuir model can be expressed mathematically as follows:

$q_{\mathrm{e}}=\frac{q_{\mathrm{m}} K_{\mathrm{L}} C_{\mathrm{e}}}{1+K_{\mathrm{L}} C_{\mathrm{e}}}$

where $q_{\mathrm{m}}$ is the maximum adsorption capacity for the adsorbent, corresponds to the monolayer surface coverage $(\mathrm{mmol} / \mathrm{g})$ and $K_{\mathrm{L}}$ is Langmuir constant represented adsorption affinity $(\mathrm{L} / \mathrm{mmol})$. The characteristic of Langmuir model can be essentially expressed by dimensionless constant called equilibrium parameter, $R_{\mathrm{L}}$, as follows [35]:

$R_{\mathrm{L}}=\frac{1}{1+K_{\mathrm{L}} C_{0}}$

The values of $R_{\mathrm{L}}$ indicate various nature of the adsorption systems to be unfavorable $\left(R_{\mathrm{L}}>1\right)$, favorable $\left(0<R_{\mathrm{L}}<1\right)$, linear $\left(R_{\mathrm{L}}=1\right)$ or irreversible $\left(R_{\mathrm{L}}=0\right)$.

The second adsorption model used in this study was Freundlich. Freundlich (1932) proposed an adsorption on surface with nonideal and reversible characteristics, which is not restricted to the monolayer adsorption [36]. To date, this model has been successfully applied to describe various adsorption systems of organics onto activated carbon and other adsorbents. However, the application of Freundlich model to evaluate adsorption data is generally valid in the narrow range of concentration since this model does not have Henry law limit at low concentration and saturation limit at high-end concentration. The Freundlich model has the following form:

$q_{\mathrm{e}}=K_{\mathrm{F}} \times C_{\mathrm{e}}^{1 / n}$

where $K_{\mathrm{F}}$ and $n$ are Freundlich constants for adsorptivity of solute $\left[(\mathrm{mmol} / \mathrm{g})(\mathrm{mmol} / \mathrm{L})^{-n}\right]$ and system heterogeneity, respectively. Higher value of $n$ denotes the more heterogeneous the system is and the system approaches a rectangular isotherm (or irreversible isotherm) when $n$ value is getting larger than about 10 [28]. The $K_{\mathrm{F}}$ constant can also be regarded as the maximum adsorption capacity of the adsorbent only when the value of $n$ approaches infinite [37].

The plots of the applied models against adsorption equilibrium data at various temperatures are depicted in Figs. 3 and 4. The values of the model parameters were obtained by nonlinear least square fitting and the results are given in Table 3. From Figs. 3 and 4, it seems that both Langmuir and Freundlich models can fit all experimental data well, as indicated by good values of correlation factor $\left(R^{2}\right)$ that lies between 0.95 and 0.99 . The values of $K_{\mathrm{L}}$ and $K_{\mathrm{F}}$ parameters seem to increase at higher temperature, denoting that higher temperature favors the adsorption process due to greater adsorptivity of dye molecules toward the adsorbent surface. The increase in affinity parameter can also be explained from kinetics viewpoint that is higher temperature provides more energy for the solutes to undergo an interaction with the active sites on the solid surface. Similar observation is also noticed in the $q_{\mathrm{m}}$ parameter, in which this value increases by the increase of temperature. Higher value of $q_{\mathrm{m}}$ for rarasaponin-bentonite is likely due to the expansion of 2:1 interlamellar distance as a result of insertion of acetyl cation, which promotes the adsorption capacity of the adsorbent for dyes removal. 
Table 3

Fitted parameters for the adsorption of MB and MG in single system at various temperatures.

\begin{tabular}{|c|c|c|c|c|c|c|c|c|c|}
\hline \multirow[t]{2}{*}{ Adsorbent } & \multirow[t]{2}{*}{ Adsorbate } & \multirow[t]{2}{*}{$T(\mathrm{~K})$} & \multicolumn{4}{|c|}{ Langmuir parameters } & \multicolumn{3}{|c|}{ Freundlich parameters } \\
\hline & & & $q_{\mathrm{m}}(\mathrm{mmol} / \mathrm{g})$ & $K_{\mathrm{L}}(\mathrm{L} / \mathrm{mmol})$ & $R^{2}$ & $R_{\mathrm{L}}$ & $\begin{array}{l}K_{\mathrm{F}}\left(\mathrm{mmol} \cdot \mathrm{g}^{-1}\right) \\
(\mathrm{mmol} / \mathrm{L})^{-1 / n}\end{array}$ & $n$ & $R^{2}$ \\
\hline \multirow[t]{6}{*}{ Bentonite } & \multirow[t]{3}{*}{ MG } & 303.15 & 0.51 & 1.56 & 0.98 & 0.19 & 0.31 & 2.73 & 0.98 \\
\hline & & 323.15 & 0.53 & 2.13 & 0.97 & 0.15 & 0.35 & 3.00 & 0.98 \\
\hline & & 343.15 & 0.56 & 3.23 & 0.99 & 0.10 & 0.41 & 3.39 & 0.99 \\
\hline & \multirow[t]{3}{*}{ MB } & 303.15 & 0.54 & 1.67 & 0.98 & 0.18 & 0.34 & 2.72 & 0.97 \\
\hline & & 323.15 & 0.57 & 2.46 & 0.97 & 0.13 & 0.37 & 3.15 & 0.97 \\
\hline & & 343.15 & 0.59 & 3.34 & 0.97 & 0.10 & 0.42 & 3.22 & 0.98 \\
\hline \multirow[t]{6}{*}{ Rarasaponin-Bentonite } & \multirow[t]{3}{*}{ MG } & 303.15 & 0.66 & 1.71 & 0.98 & 0.18 & 0.36 & 2.15 & 0.98 \\
\hline & & 323.15 & 0.87 & 2.31 & 0.98 & 0.14 & 0.47 & 2.34 & 0.97 \\
\hline & & 343.15 & 0.93 & 3.66 & 0.97 & 0.09 & 0.73 & 2.72 & 0.95 \\
\hline & \multirow[t]{3}{*}{ MB } & 303.15 & 0.71 & 1.75 & 0.99 & 0.18 & 0.41 & 2.19 & 0.98 \\
\hline & & 323.15 & 0.89 & 2.54 & 0.98 & 0.13 & 0.49 & 2.27 & 0.98 \\
\hline & & 343.15 & 0.96 & 4.13 & 0.98 & 0.08 & 0.76 & 2.81 & 0.94 \\
\hline
\end{tabular}

By comparing the fitted parameters obtained, it is known that the adsorptivity of MB dye towards the adsorbent surface is higher than MG dye. This result can be explained from molecular viewpoint that is small molecule gains easier access to the internal pore-network of the adsorbent than large molecule. MB has lower molecular weight therefore its molecular size is smaller than MG. Moreover, higher affinity of MB dye is also caused due to more stabilized positive charge at the sulfur atom as a result of the -I inductive
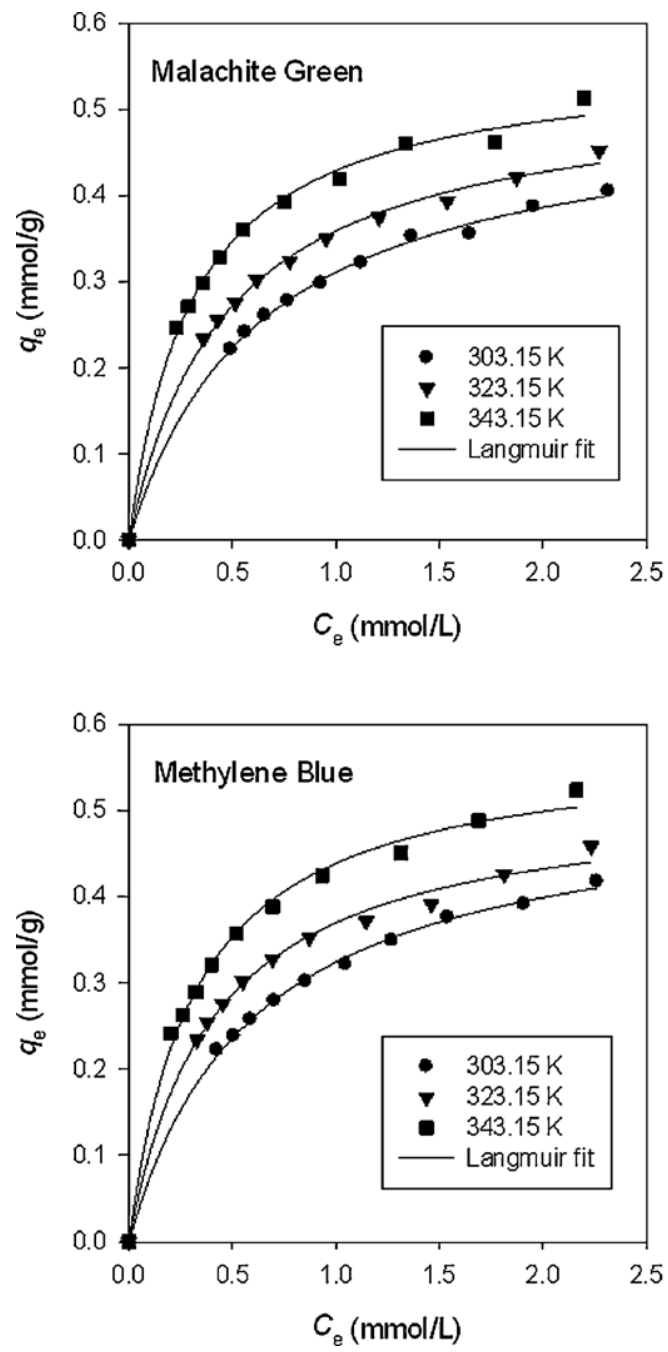

effect of the benzene ring [38], resulting in stronger dipole-dipole interaction between negatively charged oxygen atom and positively charged sulfur atom compared to negatively charged oxygen atom and positively charged nitrogen atom.

The value of $n$ parameter in Freundlich model also increases with increase of temperature. This is due to faster mobility of the adsorbate molecules in bulk solution, which rise the randomness degree of the system. The value of $n$ parameter for rarasaponin-bentonite
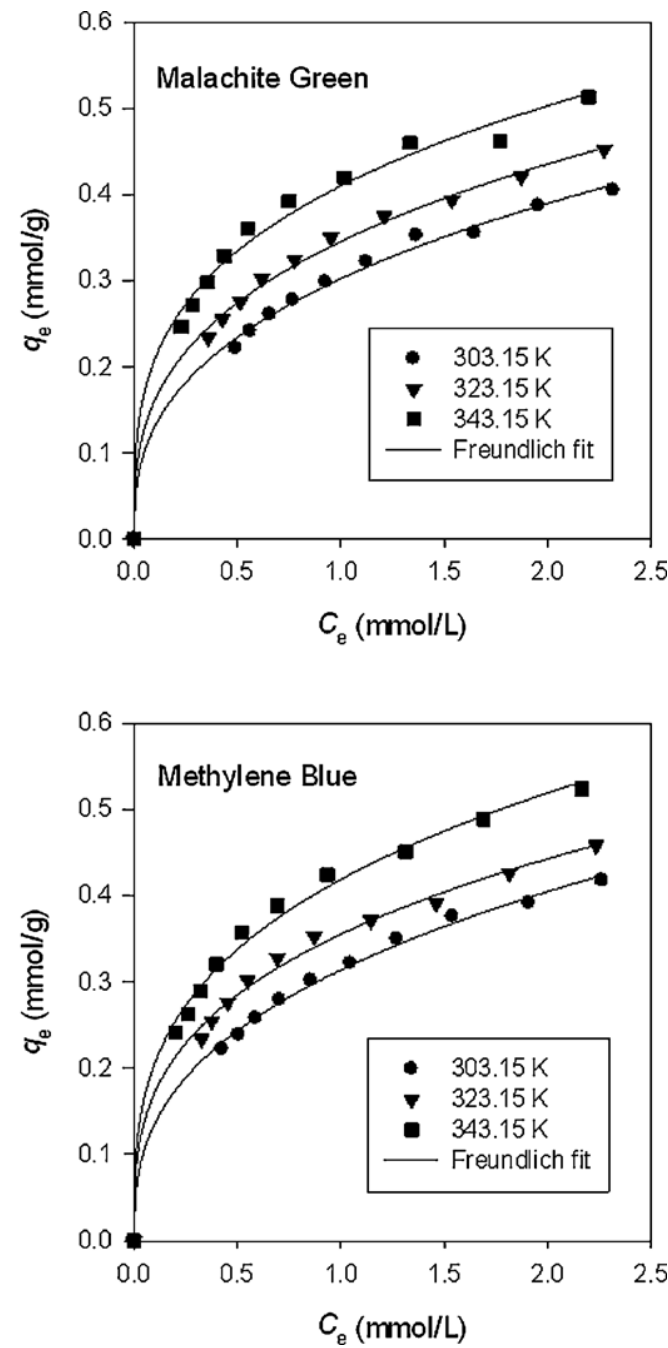

Fig. 3. Equilibrium plot and the models fit for the adsorption of MB and MG in single system onto bentonite at various temperatures. 

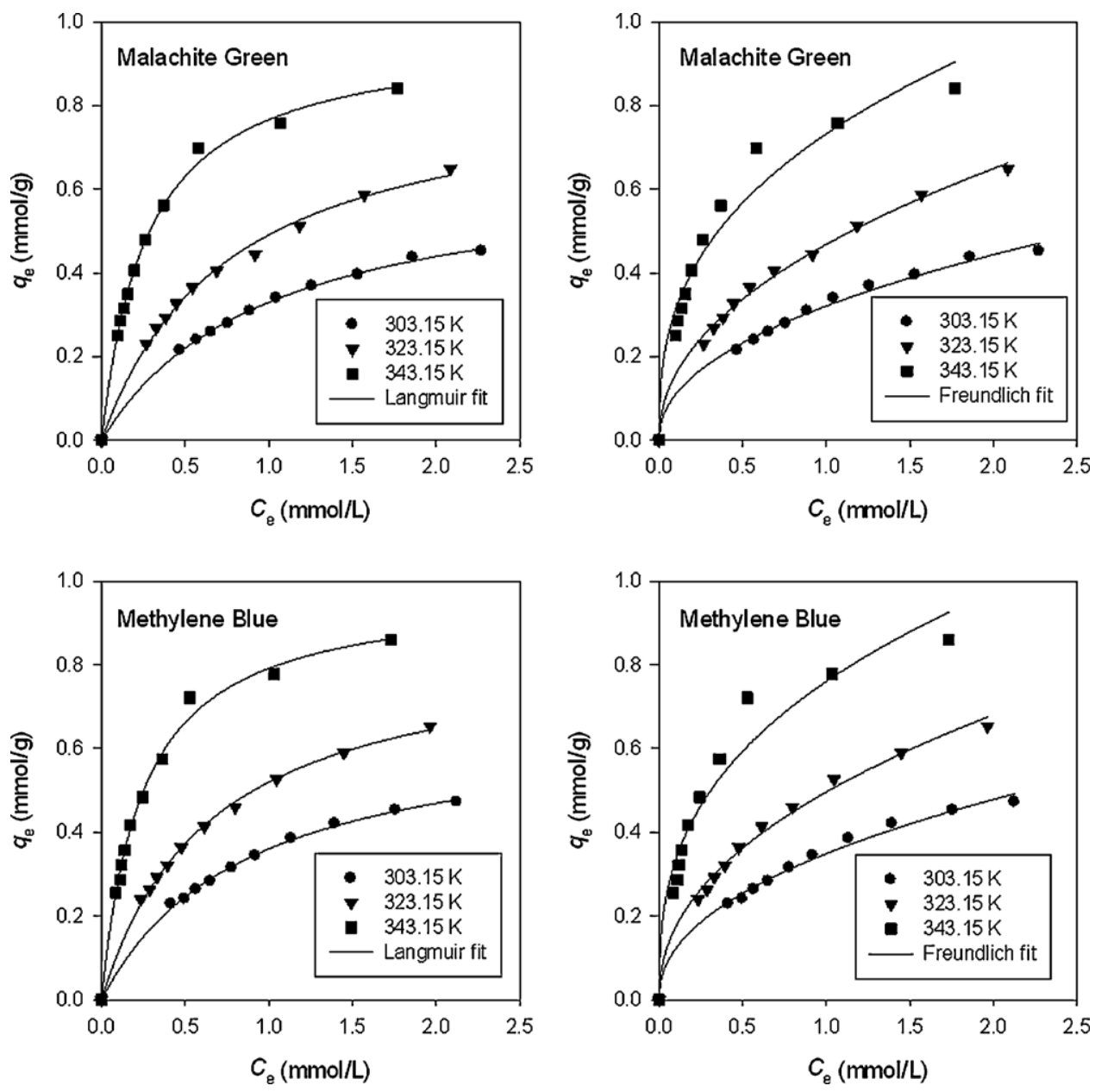

Fig. 4. Equilibrium plot and the models fit for the adsorption of MB and MG in single system onto rarasaponin-bentonite at various temperatures.

is considered to be higher than bentonite due to the present of organic modifier in the 2:1 interlayer space, causing the solid system to be more complex and heterogeneous. However, inconsistency results are noticed in this study that is the $n$ values for rarasaponin-bentonite systems are lower than bentonite systems. This result reveals that Freundlich model fails to give best representation from parameters justification. Therefore, its extended form (extended Freundlich) is not further used to evaluate adsorption equilibrium data in binary system.

\subsubsection{Adsorption isotherms for binary system}

In this study, the extended Langmuir model was used to evaluate adsorption equilibrium data in binary system. The mathematic expression of extended Langmuir model is given below:

$q_{\mathrm{e}, i}=\frac{q_{\mathrm{m}, i} K_{\mathrm{L}, i} C_{\mathrm{e}, i}}{1+\sum_{j=1}^{n} K_{\mathrm{L}, i} C_{\mathrm{e}, i}}$

For binary system, the extended Langmuir equation above becomes:

$q_{\mathrm{e}, 1}=\frac{q_{\mathrm{m}, 1} K_{\mathrm{L}, 1} C_{\mathrm{e}, 1}}{1+K_{\mathrm{L}, 1} C_{\mathrm{e}, 1}+K_{\mathrm{L}, 2} C_{\mathrm{e}, 2}}$

$q_{\mathrm{e}, 2}=\frac{q_{\mathrm{m}, 2} K_{\mathrm{L}, 2} C_{\mathrm{e}, 2}}{1+K_{\mathrm{L}, 1} C_{\mathrm{e}, 1}+K_{\mathrm{L}, 2} C_{\mathrm{e}, 2}}$

where $q_{\mathrm{m}}$ and $K_{\mathrm{L}}$ in Eqs. (9) and (10) are Langmuir constants for maximum adsorption capacity of the adsorbents $(\mathrm{mmol} / \mathrm{g})$ and adsorptivity of the adsorbates $(\mathrm{L} / \mathrm{mmol})$ in single system, respectively.
The applications of extended Langmuir model to represent adsorption equilibrium data in binary system have been reported in several studies [20-24]. From the previous studies, it was known that the evaluation of binary adsorption equilibrium data using extended Langmuir model was performed by inserting the values of $q_{\mathrm{m}}$ and $K_{\mathrm{L}}$ parameters in single system to calculate theoretical value of $q_{\mathrm{e}}$ and compared it with experimental results. However, such procedure cannot be precisely implemented for binary adsorption system although it may give good correlation result. In binary system, the competitions (total or partial) between adsorbate species for the adsorption sites on the solid surface occur and may act as the sorption-controlling factor. Such phenomena result in the coverage on the solid surface by both adsorbates with certain fractional loadings. Moreover, the adsorption potential on the surface is also affected by lateral interaction or competition between adsorbate species in the system. From the statements above, it is obvious that both $K_{\mathrm{L}}$ and $q_{\mathrm{m}}$ parameters from single Langmuir model cannot be adequately used to describe adsorption behaviors in binary system. Therefore, we proposed a revisited mathematic equation for $q_{\mathrm{m}}$ and $K_{\mathrm{L}}$ parameters for binary adsorption system as follows:

$$
q_{\mathrm{m}(\mathrm{bin})}=q_{\mathrm{m}, 1(\sin )} \theta_{1}+q_{\mathrm{m}, 2(\sin )} \theta_{2}
$$

$K_{\mathrm{L}, 1(\text { bin })}=K_{\mathrm{L}, 1(\sin )} \exp \left(\frac{-\theta_{2}}{\theta_{1}}\right)$

$$
K_{\mathrm{L}, 2(\text { bin })}=K_{\mathrm{L}, 2(\sin )} \exp \left(\frac{-\theta_{1}}{\theta_{2}}\right)
$$



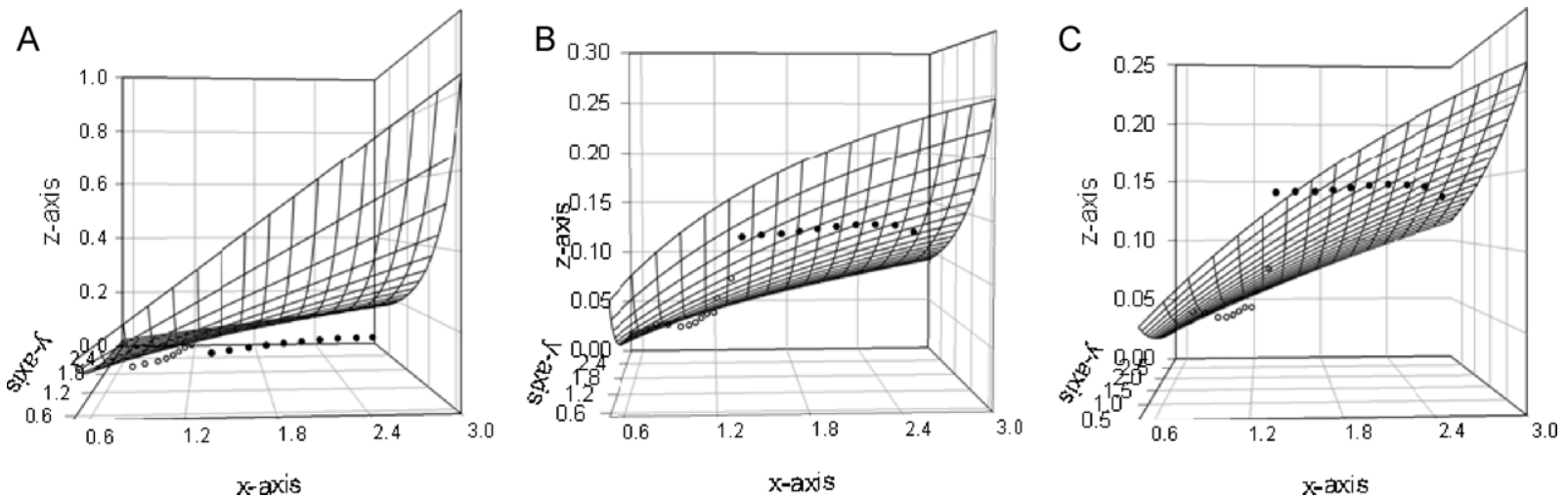

Fig. 5. Comparison plotting between original-extended Langmuir (A and B) and proposed-extended Langmuir (C) models against binary experimental data (2.74 mmol/L $\mathrm{MG}+1.34 \mathrm{mmol} / \mathrm{L} \mathrm{MB}$ - bentonite $-303.15 \mathrm{~K})$.

where $\theta_{1}$ and $\theta_{2}$ are constants representing fractional loading of each adsorbate species on the adsorbent surface. The mathematic relationship between $q_{\mathrm{m}}$ and $\theta$ is clearly understand that is the surface of the adsorbent was occupied by both adsorbates with certain loadings. In other hand, the mathematic relationship between $K_{\mathrm{L}}$ and $\theta$ can be explained principally from the surface coverage viewpoint that is the adsorption potential on the surface is weakened when the adsorbate species competed each other for the adsorption sites. Since the competition between adsorbate species occurs in binary system, therefore the values of adsorption potential (or affinity) for each adsorbate should be lower than in single system. Substitute Eqs. (11)-(13) into extended Langmuir model give:

$q_{\mathrm{e}, 1(\text { bin })}=\frac{\left(q_{\mathrm{m}, 1(\sin )} \theta_{1}+q_{\mathrm{m}, 2(\sin )} \theta_{2}\right) K_{\mathrm{L}, 1(\sin )} \exp \left(-\theta_{2} / \theta_{1}\right) C_{\mathrm{e}, 1(\mathrm{bin})}}{1+K_{\mathrm{L}, 1(\sin )} \exp \left(-\theta_{2} / \theta_{1}\right) C_{\mathrm{e}, 1(\text { bin })}+K_{\mathrm{L}, 2(\sin )} \exp \left(-\theta_{1} / \theta_{2}\right) C_{\mathrm{e}, 2(\text { (bin })}}$
$q_{\mathrm{e}, 2(\text { bin })}=\frac{\left(q_{\mathrm{m}, 1(\sin )} \theta_{1}+q_{\mathrm{m}, 2(\sin )} \theta_{2}\right) K_{\mathrm{L}, 2(\sin )} \exp \left(-\theta_{1} / \theta_{2}\right) C_{\mathrm{e}, 2(\text { bin })}}{1+K_{\mathrm{L}, 1(\sin )} \exp \left(-\theta_{2} / \theta_{1}\right) C_{\mathrm{e}, 1(\text { bin })}+K_{\mathrm{L}, 2(\sin )} \exp \left(-\theta_{1} / \theta_{2}\right) C_{\mathrm{e}, 2(\text { bin })}}$
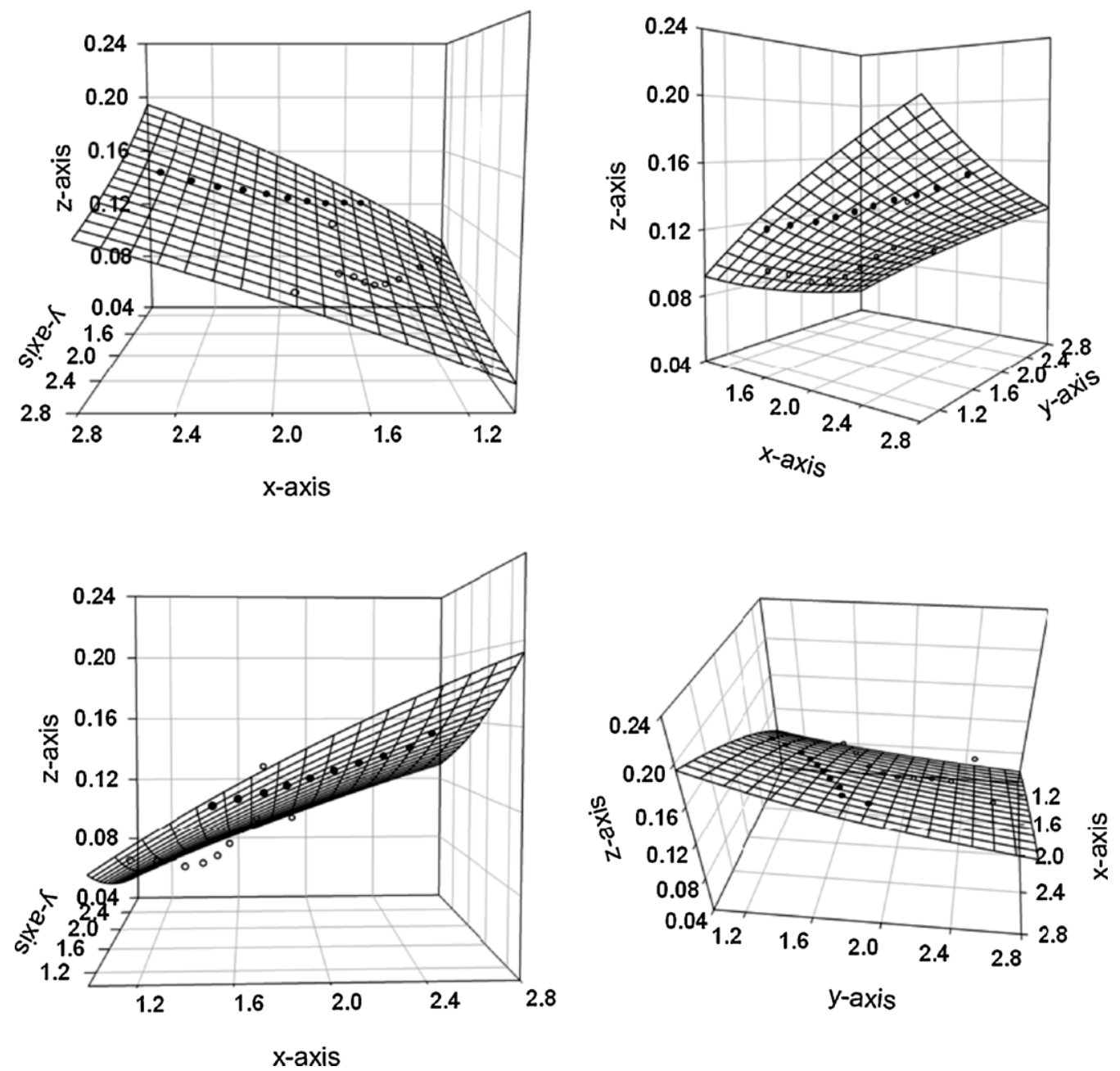

Fig. 6. Model fit of proposed-extended Langmuir at different viewpoints against binary adsorption data ( $2.74 \mathrm{mmol} / \mathrm{L} \mathrm{MG}+1.34 \mathrm{mmol} / \mathrm{L} \mathrm{MB}-\mathrm{bentonite}-303.15 \mathrm{~K})$. 

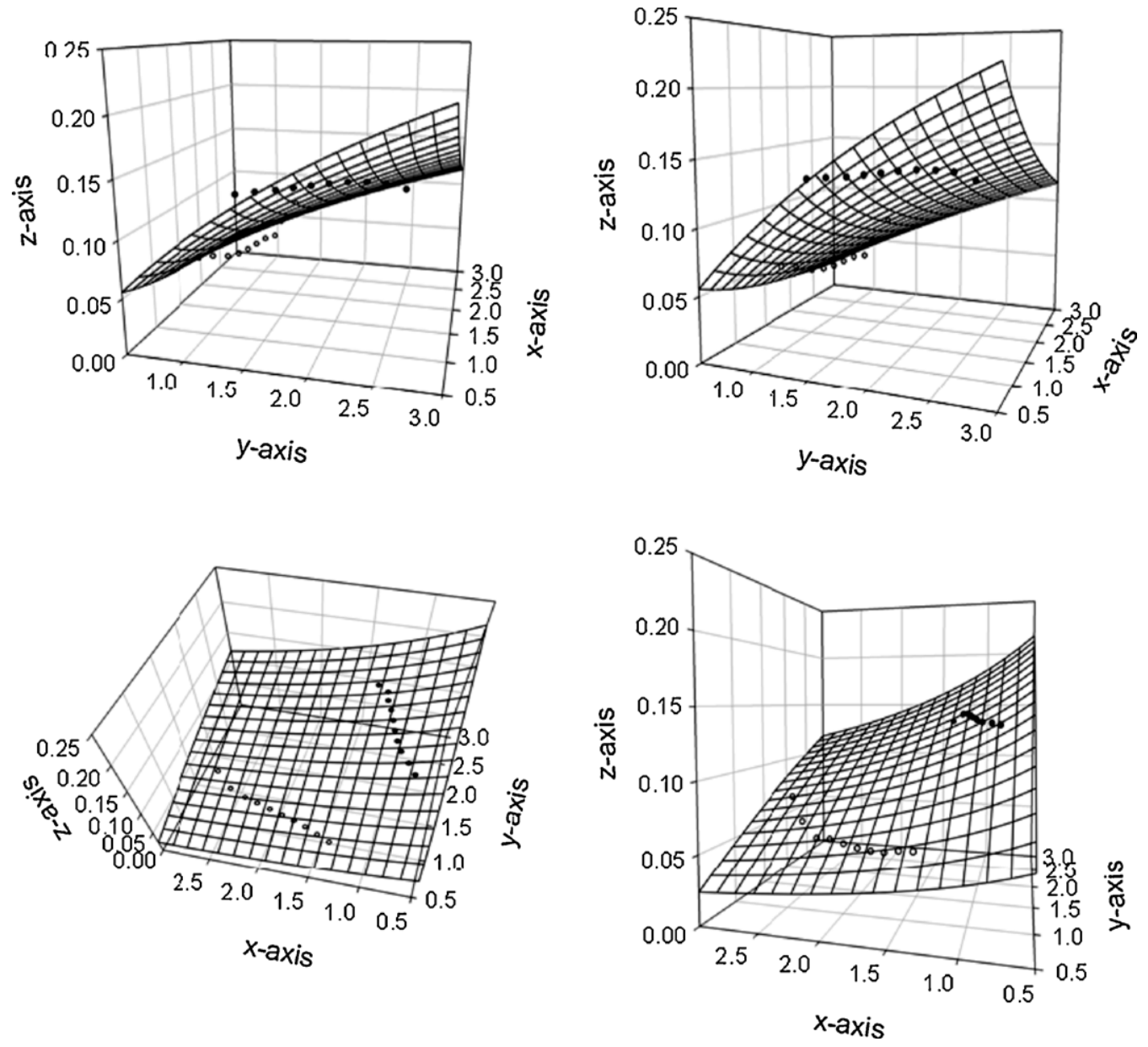

Fig. 7. Model fit of proposed-extended Langmuir at different viewpoints against binary adsorption data $(2.74 \mathrm{mmol} / \mathrm{L}$ MG $+1.34 \mathrm{mmol} / \mathrm{L}$ MB - rarasaponin-bentonite $303.15 \mathrm{~K})$.

Both equations above will return to single Langmuir model if only one adsorbate species is presented in solution (i.e. $\theta_{2}=0$ in Eq. (14) and $\theta_{1}=0$ in Eq. (15)). To get better understanding whether our model is applicable to represent binary adsorption experimental data, we compare the plot of experimental isotherm data ( $2.74 \mathrm{mmol} / \mathrm{L} \mathrm{MG}+1.34 \mathrm{mmol} / \mathrm{L} \mathrm{MB}$ - bentonite - 303.15 K) against original-extended Langmuir (Eqs. (9) and (10)) and proposedextended Langmuir models (Eqs. (14) and (15)) in 3D mesh plot, as presented in Fig. 5.

In Fig. 5, the blank data points represent the plot of $C_{\mathrm{e}, \mathrm{MB}}$ as $x$ axis vs. $C_{\mathrm{e}, \mathrm{MG}}$ as $y$-axis vs. $q_{\mathrm{e}, \mathrm{MB}}$ as $z$-axis while the filled data points denote the plot of $C_{\mathrm{e}, \mathrm{MG}}$ as $x$-axis vs. $C_{\mathrm{e}, \mathrm{MB}}$ as $y$-axis vs. $q_{\mathrm{e}, \mathrm{MG}}$ as $z-$ axis. For binary system, the plot of the model should fit both data points since the concentration of both adsorbate species in bulk solution is in a dynamic balance with the interface concentration at equilibrium condition. Fig. 5A clearly shows a very poor fit between the mesh plot and experimental data points since all data points lie below the mesh plot. This result may confirm that evaluation of binary adsorption data by comparing theoretical value of $q_{\mathrm{e}}$ with experimental results is not valid. In other hand, Fig. $5 \mathrm{~B}$ and $\mathrm{C}$ denote a very good fitting between the models and experimental data. However, the values of fitted parameters obtained from originalextended Langmuir model (Fig. 5B) are deviate away as those for single system therefore this fitting is not valid from parameters interpretation viewpoint. To this end, the value of fitted parameter obtained $\left(\theta_{1}\right)$ from proposed-extended Langmuir model (Fig. 5C) is reasonable with good correlation factor $\left(R^{2}=0.95\right)$, therefore this proposed model is further used for evaluation of binary adsorption equilibrium data in this study.

The plotting of Eqs. (14) and (15) against binary experimental data (e.g. $2.74 \mathrm{mmol} / \mathrm{L} \mathrm{MG}+1.34 \mathrm{mmol} / \mathrm{L} \mathrm{MB}$ and $2.74 \mathrm{mmol} / \mathrm{L}$ $\mathrm{MG}+1.34 \mathrm{mmol} / \mathrm{L} \mathrm{MB}$ ) onto bentonite and rarasaponin-bentonite at $303.15 \mathrm{~K}$ was performed by SigmaPlot software and the results are displayed in 3D-mesh plot (Figs. 6 and 7). The fitted parameter $\left(\theta_{1}\right)$ was obtained by nonlinear least square fitting and the results are summarized in Table 4 . The values of $q_{\mathrm{m} \text { (bin) }}, K_{\mathrm{L}, 1(\mathrm{bin})}$ and $K_{\mathrm{L}, 2 \text { (bin) }}$ parameters are calculated by inserting the value of $\theta_{1}$ parameter into Eq. (11), Eq. (12) and Eq. (13), respectively.

From Table 4, it can be seen the value of $\theta_{1}$, which refers to the fractional surface coverage by MG, decreases as the concentration of $\mathrm{MB}$ in the dye mixture increases. At the same concentration (i.e. $2.74 \mathrm{mmol} / \mathrm{L}(1000 \mathrm{mg} / \mathrm{L}) \mathrm{MG}+2.67 \mathrm{mmol} / \mathrm{L}(1000 \mathrm{mg} / \mathrm{L}) \mathrm{MB})$, the fractional loading of $\mathrm{MB}\left(\theta_{2}\right)$ is larger than MG, denoting that MB is preferentially adsorbed on the adsorbent surface than MG. This result is consistent with adsorption characteristics in single system that is the adsorptivity of MB is larger than MG, causing more coverage on the adsorbent surface. Increasing temperature also leads to the increase in affinity constants for both dyes, denoting that higher temperature favors the adsorption process. Higher value of $q_{\mathrm{m}}$ for rarasaponin-bentonite is due to larger interlamellar spaces so that more dye molecules can occupy the internal pore in the solid matrix. 
Table 4

Fitted and calculated parameters for MB and MG adsorption in binary system at various dye mixtures and temperatures.

\begin{tabular}{|c|c|c|c|c|c|c|c|c|}
\hline \multirow[t]{2}{*}{ Adsorbent } & \multirow[t]{2}{*}{ Dye mixture } & \multirow[t]{2}{*}{$T(\mathrm{~K})$} & \multirow{2}{*}{$\begin{array}{l}\text { Fitted } \\
\text { parame- } \\
\text { ter } \\
\theta_{1}\end{array}$} & \multicolumn{4}{|c|}{ Calculated parameters } & \multirow[t]{2}{*}{$R^{2}$} \\
\hline & & & & $\theta_{2}$ & $K_{\mathrm{L}, 1(\text { bin })}$ & $K_{\mathrm{L}, 2(\text { bin })}$ & $q_{\mathrm{m}(\mathrm{bin})}$ & \\
\hline \multirow[t]{12}{*}{ Bentonite } & $2.74 \mathrm{mmol} / \mathrm{L} \mathrm{MG}+0.67 \mathrm{mmol} / \mathrm{L} \mathrm{MB}$ & 303.15 & 0.57 & 0.43 & 0.74 & 0.44 & 0.51 & 0.88 \\
\hline & $2.74 \mathrm{mmol} / \mathrm{L} \mathrm{MG}+1.34 \mathrm{mmol} / \mathrm{L} \mathrm{MB}$ & & 0.51 & 0.49 & 0.60 & 0.59 & 0.51 & 0.95 \\
\hline & $2.74 \mathrm{mmol} / \mathrm{L} \mathrm{MG}+2.01 \mathrm{mmol} / \mathrm{L} \mathrm{MB}$ & & 0.42 & 0.58 & 0.39 & 0.81 & 0.52 & 0.94 \\
\hline & $2.74 \mathrm{mmol} / \mathrm{L} \mathrm{MG}+2.67 \mathrm{mmol} / \mathrm{L} \mathrm{MB}$ & & 0.36 & 0.64 & 0.26 & 0.95 & 0.52 & 0.91 \\
\hline & $2.74 \mathrm{mmol} / \mathrm{L} \mathrm{MG}+0.67 \mathrm{mmol} / \mathrm{L} \mathrm{MB}$ & 323.15 & 0.55 & 0.45 & 0.94 & 0.73 & 0.53 & 0.91 \\
\hline & $2.74 \mathrm{mmol} / \mathrm{L} \mathrm{MG}+1.34 \mathrm{mmol} / \mathrm{L} \mathrm{MB}$ & & 0.49 & 0.51 & 0.75 & 0.94 & 0.54 & 0.89 \\
\hline & $2.74 \mathrm{mmol} / \mathrm{L} \mathrm{MG}+2.01 \mathrm{mmol} / \mathrm{L} \mathrm{MB}$ & & 0.38 & 0.62 & 0.42 & 1.15 & 0.54 & 0.88 \\
\hline & $2.74 \mathrm{mmol} / \mathrm{L} \mathrm{MG}+2.67 \mathrm{mmol} / \mathrm{L} \mathrm{MB}$ & & 0.33 & 0.67 & 0.28 & 1.30 & 0.54 & 0.93 \\
\hline & $2.74 \mathrm{mmol} / \mathrm{L} \mathrm{MG}+0.67 \mathrm{mmol} / \mathrm{L} \mathrm{MB}$ & 343.15 & 0.51 & 0.49 & 1.24 & 1.18 & 0.56 & 0.92 \\
\hline & $2.74 \mathrm{mmol} / \mathrm{L} \mathrm{MG}+1.34 \mathrm{mmol} / \mathrm{L} \mathrm{MB}$ & & 0.45 & 0.55 & 0.95 & 1.47 & 0.57 & 0.91 \\
\hline & $2.74 \mathrm{mmol} / \mathrm{L} \mathrm{MG}+2.01 \mathrm{mmol} / \mathrm{L} \mathrm{MB}$ & & 0.34 & 0.66 & 0.46 & 1.99 & 0.57 & 0.93 \\
\hline & $2.74 \mathrm{mmol} / \mathrm{L} \mathrm{MG}+2.67 \mathrm{mmol} / \mathrm{L} \mathrm{MB}$ & & 0.31 & 0.69 & 0.35 & 2.13 & 0.57 & 0.94 \\
\hline \multirow[t]{12}{*}{ Rarasaponin-bentonite } & $2.74 \mathrm{mmol} / \mathrm{L} \mathrm{MG}+0.67 \mathrm{mmol} / \mathrm{L} \mathrm{MB}$ & 303.15 & 0.53 & 0.47 & 0.70 & 0.57 & 0.66 & 0.95 \\
\hline & $2.74 \mathrm{mmol} / \mathrm{L} \mathrm{MG}+1.34 \mathrm{mmol} / \mathrm{L} \mathrm{MB}$ & & 0.46 & 0.54 & 0.53 & 0.75 & 0.66 & 0.91 \\
\hline & $2.74 \mathrm{mmol} / \mathrm{L} \mathrm{MG}+2.01 \mathrm{mmol} / \mathrm{L} \mathrm{MB}$ & & 0.38 & 0.62 & 0.34 & 0.95 & 0.67 & 0.89 \\
\hline & $2.74 \mathrm{mmol} / \mathrm{L} \mathrm{MG}+2.67 \mathrm{mmol} / \mathrm{L} \mathrm{MB}$ & & 0.32 & 0.68 & 0.20 & 1.09 & 0.67 & 0.91 \\
\hline & $2.74 \mathrm{mmol} / \mathrm{L} \mathrm{MG}+0.67 \mathrm{mmol} / \mathrm{L} \mathrm{MB}$ & 323.15 & 0.49 & 0.51 & 0.82 & 0.97 & 0.87 & 0.94 \\
\hline & $2.74 \mathrm{mmol} / \mathrm{L} \mathrm{MG}+1.34 \mathrm{mmol} / \mathrm{L} \mathrm{MB}$ & & 0.44 & 0.56 & 0.65 & 1.16 & 0.87 & 0.93 \\
\hline & $2.74 \mathrm{mmol} / \mathrm{L} \mathrm{MG}+2.01 \mathrm{mmol} / \mathrm{L} \mathrm{MB}$ & & 0.35 & 0.65 & 0.36 & 1.48 & 0.88 & 0.91 \\
\hline & $2.74 \mathrm{mmol} / \mathrm{L} \mathrm{MG}+2.67 \mathrm{mmol} / \mathrm{L} \mathrm{MB}$ & & 0.30 & 0.70 & 0.22 & 1.66 & 0.88 & 0.95 \\
\hline & $2.74 \mathrm{mmol} / \mathrm{L} \mathrm{MG}+0.67 \mathrm{mmol} / \mathrm{L} \mathrm{MB}$ & 343.15 & 0.47 & 0.53 & 1.19 & 1.70 & 0.96 & 0.89 \\
\hline & $2.74 \mathrm{mmol} / \mathrm{L} \mathrm{MG}+1.34 \mathrm{mmol} / \mathrm{L} \mathrm{MB}$ & & 0.41 & 0.59 & 0.87 & 2.06 & 0.97 & 0.92 \\
\hline & $2.74 \mathrm{mmol} / \mathrm{L} \mathrm{MG}+2.01 \mathrm{mmol} / \mathrm{L} \mathrm{MB}$ & & 0.31 & 0.69 & 0.40 & 2.64 & 0.97 & 0.94 \\
\hline & $2.74 \mathrm{mmol} / \mathrm{L} \mathrm{MG}+2.67 \mathrm{mmol} / \mathrm{L} \mathrm{MB}$ & & 0.27 & 0.73 & 0.25 & 2.85 & 0.97 & 0.91 \\
\hline
\end{tabular}

\section{Conclusions}

Preparation of rarasaponin-bentonite via microwave radiation has been demonstrated in this work. Batch adsorption experiments at three different temperatures were performed to test adsorption performance of bentonite and rarasaponin-bentonite for the removal of methylene blue and malachite green in single and binary systems. Experimental isotherms in single systems were analyzed by Langmuir and Freundlich models and their fitting results were contrasted. From physical meaning interpretation of the model parameters, it was found that Langmuir model gave the best representation. For binary system, experimental isotherms were presented in the $3 \mathrm{D}$ mesh plot and were interpreted using extended Langmuir model incorporating fractional surface coverage $(\theta)$. The results show that recently proposed modification of extended Langmuir model can be used to describe binary adsorption experimental data well with reasonable fitted parameter value.

\section{Appendix A. Supplementary data}

Supplementary data associated with this article can be found, in the online version, at doi:10.1016/j.cej.2012.02.070.

\section{References}

[1] S. Chowdhury, P. Saha, Sea shell powder as a new adsorbent to remove basic green 4 (malachite green) from aqueous solutions: equilibrium, kinetic and thermodynamic studies, Chem. Eng. J. 164 (2010) 168-177.

[2] C.I. Pearce, J.R. Lloyd, J.T. Guthrie, The removal of colour from textile wastewater using whole bacterial cells: a review, Dyes Pigments 58 (2003) 179-196.

[3] S.D. Khattri, M.K. Singh, Colour removal from dye wastewater using sugar cane dust as an adsorbent, Adsorpt. Sci. Technol. 17 (1999) 269-282.

[4] O. Hamdaoui, Dynamic sorption of methylene blue by cedar sawdust and crushed brick in fixed bed columns, J. Hazard. Mater. 138 (2006) 293-303.

[5] A.R. DiSanto, J.G. Wagner, Pharmacokinetics of highly ionized drugs. II. Methylene blue - absorption, metabolism, and excretion in man and dog after oral administration, J. Pharm. Sci. 61 (1972) 1086-1090.

[6] J.W. Harvey, A.S. Keitt, Studies of the efficacy and potential hazards of methylene blue therapy in aniline-induced methaemoglobinaemia, Br. J. Haematol. 54 (1983) 29-41.
[7] E. Sudova, J. Machova, Z. Svobodova, T. Vesely, Negative effects of malachite green and possibilities of its replacement in the treatment of fish eggs and fish: a review, Vet. Med. 52 (2007) 527-539.

[8] C. Fernandez, M.S. Larrechi, M.P. Callao, An analytical overview of processes for removing organic dyes from wastewater effluents, Trends Anal. Chem. 29 (2010) 1202-1211.

[9] V.K. Gupta, Suhas, Application of low-cost adsorbents for dye removal - a review, J. Environ. Manage. 90 (2009) 2313-2342.

[10] A. Kurniawan, H. Sutiono, H.-Y. Ju, F.E. Soetaredjo, A. Ayucitra, A. Yudha, S. Ismadji, Utilization of rarasaponin natural surfactant for organo-bentonite preparation: application for methylene blue removal from aqueous effluent, Micropor. Mesopor. Mater. 142 (2011) 184-193.

[11] S. Netpradit, P. Thiravetyan, S. Towprayoon, Evaluation of metal hydroxide sludge for reactive dye adsorption in a fixed-bed column system, Water Res. 38 (2004) 71-78.

[12] G. Annadurai, R.S. Juang, D.J. Lee, Use of cellulose-based wastes for adsorption of dyes from aqueous solution, J. Hazard. Mater. 92 (2002) 263-274.

[13] Y.S. Ho, C.C. Chiang, Y.C. Hsu, Sorption kinetics for dye removal from aqueous solution using activated clay, Sep. Purif. Technol. 36 (2001) 2473-2488.

[14] Q. Li, Q.-Y. Yue, H.-J. Sun, Y. Su, B.-Y. Gao, A comparative study on the properties, mechanisms and process designs for the adsorption of non-ionic or anionic dyes onto cationic-polymer/bentonite, J. Environ. Manage. 91 (2010) 1601-1611.

[15] O. Gok, A.S. Ozcan, A. Ozcan, Adsorption behavior of a textile dye of Reactive Blue 19 from aqueous solutions onto modified bentonite, Appl. Surf. Sci. 256 (2010) 5439-5443.

[16] H.A. Patel, R.S. Somani, H.C. Bajaj, R.V. Jasra, Synthesis and characterization of organic bentonite using Gujarat and Rajasthan clays, Curr. Sci. 92 (2007) 1004-1009.

[17] B. Zohra, K. Aicha, S. Fatima, B. Nourredine, D. Zoubir, Adsorption of Direct Red 2 on bentonite modified by cetyltrimethylammonium bromide, Chem. Eng. J. 136 (2008) 295-305.

[18] P. Baskaralingam, M. Pulikesi, V. Ramamurthi, S. Sivanesan, Modified hectorites and adsorption studies of a reactive dye, Appl. Clay Sci. 37 (2007) 207-214.

[19] J. Li, L. Zhu, W. Cai, Microwave enhanced-sorption of dyestuffs to dual-cation organobentonites from water, J. Hazard. Mater. 136 (2006) 251-257.

[20] K.K.H. Choy, J.F. Porter, G. McKay, Langmuir isotherm models applied to the multicomponent sorption of acid dyes from effluent onto activated carbon, J. Chem. Eng. Data 45 (2000) 575-584.

[21] K.K.H. Choy, S.J. Allen, G. McKay, Multicomponent equilibrium studies for the adsorption of basic dyes from solution on lignite, Adsorption 11 (2005) 255-259.

[22] K.S. Baig, H.D. Doan, Ju Wu, Multicomponent isotherms for biosorption of $\mathrm{Ni}^{2+}$ and $\mathrm{Zn}^{2+}$, Desalination 249 (2009) 429-439.

[23] G. Atun, E.T. Acar, Competitive adsorption of basic dyes onto calcite in single and binary component systems, Sep. Sci. Technol. 45 (2010) 1471-1481. 
[24] S. Chakraborty, J.K. Basu, S. De, S.D. Gupta, Adsorption of reactive dyes from textile effluent using sawdust as the adsorbent, Ind. Eng. Chem. Res. 45 (2006) 4732-4741.

[25] A.K. Rahardjo, M.J.J. Susanto, A. Kurniawan, N. Indraswati, S. Ismadji, Modified ponorogo bentonite for the removal of ampicillin from wastewater, J. Hazard. Mater. 190 (2011) 1001-1009.

[26] P.C.C. Faria, J.J.M. Orfao, M.F.R. Pereira, Adsorption of anionic and cationic dyes on activated carbons with different surface chemistries, Water Res. 38 (2004) 2043-2052.

[27] A. Saeed, M. Sharif, M. Iqbal, Application potential of grapefruit peel as dye sorbent: kinetics, equilibrium and mechanism of crystal violet adsorption, J. Hazard. Mater. 179 (2010) 564-572.

[28] D.D. Do, Adsorption Analysis: Equilibria and Kinetics, Imperial College Press, London, 1998.

[29] A. Seker, T. Shahwan, A.E. Eroglu, S. Yilmaz, Z. Demirel, M.C. Dalay, Equilibrium, thermodynamic and kinetic studies for the biosorption of aqueous lead(II), cadmium(II) and nickel(II) ions on Spirulina platensis, J. Hazard. Mater. 154 (2008) 973-980.

[30] A. Kurniawan, A.N. Kosasih, J. Febrianto, H.-Y. Ju, J. Sunarso, N. Indraswati, S. Ismadji, Evaluation of cassava peel waste as lowcost biosorbent for $\mathrm{Ni}$ sorption: equilibrium, kinetics, thermodynamics and mechanism, Chem. Eng. J. 172 (2011) 158-166
[31] S. Kalyani, P.S. Rao, A. Krishnaiah, Removal of nickel(II) from aqueous solutions using marine macroalgae as the sorbing biomass, Chemosphere 57 (2004) 1225-1229.

[32] A. Khenifi, B. Zohra, B. Kahina, H. Houari, D. Zoubir, Removal of 2,4-DCP from wastewater by $\mathrm{CTAB}$ /bentonite using one-step and two-steps methods: a comparative study, Chem. Eng. J. 146 (2009) 345-354

[33] E.N. El Qada, S.J. Allen, G.M. Walker, Adsorption of basic dyes from aqueous solution onto activated carbons, Chem. Eng. J. 135 (2008) 174-184.

[34] I. Langmuir, The constitution and fundamental properties of solids and liquids, J. Am. Chem. Soc. 38 (1916) 2221-2295.

[35] T.W. Weber, R.K. Chakravorti, Pore and solid diffusion models for fixed-bed adsorbers, AIChE J. 20 (1974) 228-238

[36] H.M.F. Freundlich, Over the adsorption in solution, J. Phys. Chem. 57 (1906) $385-471$.

[37] X. Lu, Comment on thermodynamic and isotherm studies of the biosorption of $\mathrm{Cu}(\mathrm{II}), \mathrm{Pb}(\mathrm{II})$, and $\mathrm{Zn}(\mathrm{II})$ by leaves of saltbush (Atriplex canescens), J. Chem. Thermodyn. 40 (2008) 739-740.

[38] A.E. Ofomaja, Kinetic study and sorption mechanism of methylene blue and methyl violet onto Mansonia (Mansonia altissima) wood sawdust, Chem. Eng. J. 143 (2008) 85-95. 